\title{
Re-imagining the Ghetto: Introduction to the Forum "The Ghetto as a Victorian Text"
}

\author{
Shaul Bassi \\ Ca'Foscari University, Venice
}

The term Grand Tour, the "great journey" to Southern Europe that defined the education of many European and later American gentlemen, appeared in 1670 in Voyage of Italy, or a Complete Journey through Italy by Richard Lassels. In his passage to Venice, which would become an indispensable station in any standard itinerary, this English Catholic priest paid a visit to the Jewish Ghetto:

we went after dinner one Saturday to see the Jews Synagogue.

Among other things I heard here a Rabbin make a Homily to his flock. He looked like a French Minister, or Puritanical Lecturer, in a short cloak and hat. The hissing through the nose made all the edification that I saw in it: it was in Italian, but the coldest discourse that I ever heard in any language. (1670: 422) 
Curiously enough, the episode echoes — rather suspiciously — an experience enjoyed by Thomas Coryat in 1608 . This formidable traveller, who after Italy reached Persia and India, also entered a synagogue in the Ghetto. He was also initially unimpressed by the rabbi pronunciation in reading (I was trying to avoid the repetition of 'reading', which is used in the quote. Reciting?) from the Torah: "not by a sober, distinct, and orderly reading, but by an exceeding loud yawling, undecent roaring, and as it were a beastly bellowing of it forth." However, his visit also gave him the opportunity to confront some typical prejudices of an England that had long before expelled its Jews:

I observed some few of those Jews especially some of the Levantines to be such goodly and proper men, that then I said to myself our English proverb: To look like a Jew (whereby is meant sometimes a weather beaten warpfaced fellow, sometimes a frantic and lunatic person, sometimes one discontented), is not true. (2013: 77-78)

The Ghetto of Venice appears here as a place of cross-cultural exchange and misunderstanding (no contradiction between the two aspects), a contact zone that 
stimulates interrogation and translation, comparison and projection, prejudice and discovery. But after these two early modern forays, the site disappeared from the Grand Tour, and never featured when the travelling experience was transfigured into the realm of poetry and fiction that would make of Venice a great literary trope. We do not find it in Ruskin, Mann, James, or Proust. Byron could ride his horse into the Jewish cemetery where the residents of the Ghetto had been burying their dead for centuries, but the intellectual curiosity that brought him regularly to the Armenian library or his biblical interests expressed in the Hebrew Melodies did not inspire him to visit the Ghetto, or at least to leave any record of such a trip. Admittedly, by the time Byron had arrived in the city, the Ghetto, established in 1516, had ceased to be a totally segregated space, after Napoleon had burned its gates and enabled a partial emancipation of the Jews in 1797. Théophile Gautier happened upon the place in 1850 but saw it entirely through the lens of orientalist and antisemitic stereotypes: "This fetid and purulent quarter, this aquatic Court of miracles, was indeed the Ghetto, the Jewry of Venice, which has preserved the characteristic sordidness of the Middle Ages" (1912: 265). The American William Dean Howells gave a more accurate portrait of it in his Venetian Life (1866) and yet could not avoid religious and racial prejudices.

The Ghetto, and its equivalents in Florence and Rome, reappear in various 
Victorian texts. The five engaging essays of this forum show, from different and fruitfully complementary angles, how the renewed interest in the Italian Ghettos served two late Victorian writers, Israel Zangwill and Amy Levy, to reflect on their own modern British and Jewish identity.

In his illuminating overview, Murray Baumgarten shows how Zangwill used the Venice Ghetto as paradigmatic of the modern Jewish experience. In order to understand the changing social and urban configurations of the Jewish streets of London, "Zangwill turned to the history of the Venice Ghetto — the first modern Jewish space and a laboratory of Jewish modernity — which becomes the subtext of his exploration." No longer just a physical space, the Ghetto was internalized as a state of mind and became in modern times "a psychological force, and even . . . a central trope in the discourse of modern Jewish experience." Zangwill was forced into an either/or situation where the Jewish identity and language, seen as residual, and the hegemonic discourse of Englishness were cast as incompatible, without the possibility of that multiculturalism and hybridity that would emerge as cultural models only much later (replacing that homogenizing "melting pot," a phrase launched by Zangwill). In a precious insight into the relation between language and space, Baumgarten finally reads Zangwill in the broader historical and transnational context of Jewish literature, reminding us that it took different places to 
develop an English-language literature that could express a self-confident Jewish identity: "The greater freedom of American life — the greater openness of its spaces and its developing built environment — is central to their syntax and their American-Jewish discourse."

As Heidi Kaufman next explains in "Borders of Intimacy in Israel Zangwill's Children of the Ghetto," Zangwill was not just a first-hand witness. As he was describing the London Ghettos, he was writing in the wake of and partially against other contemporary accounts of these Jewish quarters in London, such as W. M. Thackeray, Watt Phillips, and anonymous authors. Kaufman usefully adopts the conceptual tools of affect theory to demonstrate that "all of Zangwill's ghetto fictions suggest that the ghetto's trappings are not just a function of the borders, but are part of the affective circuits within which ghetto culture thrives." Focussing on Zangwill's heroine Esther Ansell, she also shows that the emotional intimacy and attachment of this character to the Jewish enclave in which she spent her childhood is not only a form of limitation but also a powerful cognitive force: "Esther's bodily encounter, her intimate experiences within the ghetto, do indeed insist upon emotion; but they also drive her toward knowledge and movement, toward ways of knowing the ghetto and the world beyond through her bodily encounters." As in the case of this character, Zangwill's own vision is made broader by a powerful 
combination of "proximity and objectivity, intimacy and distance, emotional pull and detachment."

If the Ghetto can be a text, the text — broadly conceived as any representation — can also be a Ghetto. In "Confronting the 'Jewish Type': Israel Zangwill, Composite and Mirror Photography," Amanda Kaye Sharick chooses the original perspective of photographic technique to show how Zangwill both adopts and subverts a point of view that had been developed in some of his contemporary photographic experiments. Applied to the socially and ethnically diverse Jewish society of late Victorian London, composite photography sought to overcome these internal differences by casting a single Jewish type and developing a racialized identity. Zangwill struggled with this notion of a "Jewish type" and with all stereotypes of Jewishness, even when they were positive, as reductive. Throughout his career, he contested "the composite photographic logic of liberalism, which predicated tolerance on the radical assimilation of Jewish difference and sutured national progress to the institutional mechanisms for managing populations through typologies," since he believed that "Jewishness was far too diverse to be subsumed in a single image." While opposing the logic of composite photography, Zangwill did not shy away from the implications of mirror photography: as Sharick suggests, "he uses a literary version of the hinged-mirror technique to hold in tension the 
productive multiplicity and the violent fragmentation of modern Jewish identity." The same counter-logic led Zangwill to embrace cosmopolitanism and pacifism after a departure from Zionism.

Meri-Jane Rochelson’s “Israel Zangwill’s Italian Fantasies: Constructing a Self beyond the Ghetto" brings us back to the subject of the Grand Tour, through an analysis of Zangwill's non-fictional reports on his Italian trips. Even if he may have envisioned these chronicles to prove that he could write as authoritatively on nonJewish topics as any other English writer abroad, according to Rochelson "there is much that is Jewish in Italian Fantasies, available both to admirers of Zangwill as a Jewish writer and to his detractors." Even when dealing with Italy at large, Zangwill was positioned as a Jewish author, "aiming to transcend aesthetically confining ghetto walls while at the same time seeking to establish himself as a writer with a right of ownership to wider European culture." While his discussion of major Italian monuments and artefacts allowed Zangwill to articulate a vision of Western art that today we would call a Judeo-Christian vision, it was paradoxically his open anti-Catholic sentiment that both aligned with the standard Anglican view of Italy and caused him to be accused of hostility to Christianity.

In “"Poor Old Palace-Prison!': Jewish Urban Memory in Amy Levy’s ‘The Ghetto at Florence' (1886)," Richa Dwor takes us to the other favorite destination 
of British travellers and to an author who chose Florence to write for the first time from the point of view of an assimilated English Jew. In her essay Levy addressed the history of Jewish exclusion and confinement represented by the ghetto of Florence, "while also using this site to engage her complex attitudes towards Jewishness in the mid-1880s, in London." The role of gender is also prominent in Dwor's analysis, leading her to define Levy's narrator as “an urban observer, possibly even a female flâneur [who] moves freely and makes her solitary progress into and out of the ghetto, ... identifies herself as a Jew, and ... is concerned with the subjectivity of her experience." Moving in space, Levy also travelled in history, connecting the early modern to the contemporary, negotiating Jewish and English identities through memory, wit, and social observation. Interestingly enough, she also got enmeshed in the discourse of race, even though in the Italian context she often had a hard time telling the Jews from other Italians.

After Zangwill's landmark texts, few writers returned to the Ghetto of Venice until the late 20th century, with an unavoidable post-Holocaust perspective. There is a curious contradiction in the fact that thousands of physical and metaphorical sites in the world still take their name from this Ghetto and relatively little literature has been written about it. A recent account by the Australian author Arnold Zable summarizes the salient features of its society: 
The ghetto was isolated, yet its isolation protected its residents. And they took their chances. They created a mini civilisation, a city within the city, invested it with its own myths, its subtle glories. Some came to see it as a biblical camp of the Hebrews, a miniature Jerusalem, a way stop for scholars and pilgrims. There were five synagogues, one each for the German, Italian, Spanish, French and Levantine communities that settled here, each community with its history of dispossession, its journey in search of a new way to scrape a living. They made the ghetto a centre of culture, complete with literary salons, an academy of music, a theatre, and a place of commerce with inns for merchants and travellers. (2012: 116-17)

The cultural achievements of this mini-civilization could not be the relevant ones for Zangwill and the other writers oriented to the emancipation of the Jews rather than to the creative potentialities of the Ghetto. In his essay, Baumgarten cites the contemporary British Jewish writer Linda Grant to suggest that ultimately the influence of the Ghetto has never left: "The minds of Jews in Europe are thoroughly colonized, and have no means of escape from it, because that is the nature of diaspora. . . . outside of America and Israel, Jewish life is marginal and uncertain." 
It is interesting how American and Israeli Jewish identities continue to need old Europe as a negative model. Grant's sweeping generalization begs the question of whether being part of a majority (as in Israel) or a model minority (as in the US) makes the mind necessarily less colonized by non-Jewish models, or whether the marginality and uncertainty of Europe can also be a vantage point to resist colonization. In Zangwill's tragic short story “Chad Gadya," his Venetian Jewish protagonist realizes that he is unable to harmonize the religious traditions of his family with the secular culture he has been acquiring in Vienna and drowns himself. Had he lived he might have become one of the many Italian Jews persecuted by fascism even as they had fully assimilated into Italian society. But, paradoxically, if this tragic character had returned to his roots, to the society of the Ghetto of the 16th and 17 th centuries encountered by Lassels and Coryate and chronicled from within by Leon Modena in his extraordinary Life of Judah or by Sarra Copia Sullam's works, he would have found cultural models where Jewish traditions, languages, and rites coexisted and negotiated with the idioms and forms of mainstream Christian culture. In view of the 500th anniversary of the establishment of the Ghetto to be marked in 2016, several contemporary writers have been invited to Venice to re-imagine the place in a Jewish and multicultural perspective. They are the ideal readers of Zangwill, Levy, and their contemporary critics; and the 
essays of this forum are invaluable in highlighting both a crucial moment of reconfiguration of British Jewish identity and the continuing global relevance of the Ghetto.

\section{Works Cited}

Coryat, Thomas. 2013. Most Glorious \& Peerless Venice. Ed. D. Whittaker. Charlbury: Wavestone Press.

Gautier, Théophile. 1912. The Travels of Théophile Gautier. Boston: Little, Brown. Lassels, Richard. 1670. Voyage of Italy, or a Complete Journey through Italy.

Paris: Vincent de Moutier.

Modena, Leon. 1988. The Autobiography of a Seventeenth-Century Rabbi: Leon Modena's Life of Judah. Ed. Mark R. Cohen. Princeton: Princeton University Press.

Zable, Arnold. 2012. Violin Lessons. Melbourne: Text Publishing. 